\title{
Produçao de diferentes forrageiras durante o outono na região norte do Paraná
}

Marcelo Alves da Silva”, José Carlos Arevalo Júnior, Giancarlo Dalla Costa, Daniel Sampaio Ferreira Lima, Luis Murilo Ferraz de Almeida, Leopoldo Sussumu Matsumoto, Gilberto Bueno Demétrio, Petrônio Pinheiro Porto

Universidade Estadual do Norte do Paraná (UENP), Bandeirantes, PR, Brasil

*Autor correspondente

e-mail: masilva@uenp.edu.br

\section{Resumo}

A pecuária de corte brasileira está fundamentada no uso de gramíneas tropicais, que apresentam alta produção forrageira no verão e baixa no inverno. Como alternativa no inverno, podemos utilizar forragens de clima temperado. 0 Sistema de Produção de Integração Lavoura-Pecuária, somado à possibilidade da sobressemeadura, motivou este trabalho, que teve como objetivo avaliar a produção de massa de forrageiras tropicais e temperadas durante o outono e inverno na região norte do Paraná (região de transição entre clima tropical e subtropical). Os tratamentos foram: Aveia Preta (Avena strigosa) (AV), Aveia Preta consorciada com Azevém (Lolium multiflorum) (AVAZ), Milheto (Pennisetum americanum L), Milheto consorciado com Aveia Preta (AVMI), Capim Mulato (Brachiaria hibrida cv. mulato) (MU) e Capim Sudão (Sorghum sudanense) (SU). Realizou-se a sobressemeadura na soja (estádio R8 antes da queda das folhas) no dia 14 de março de 2013. 0 tamanho das parcelas foi de $30 \mathrm{~m}^{2}$ (5X6). 0 tipo de delineamento foi o de blocos casualizados com quatro repetições. Os dados foram submetidos à análise estatística utilizando teste de Tukey (5\%). A colheita da soja (dia zero do ciclo forrageiro) ocorreu 13 dias após a sobressemeadura. Foram realizados cortes nos dias 70 e 105 do ciclo forrageiro. Houve um período de estiagem acentuado do dia 18 até o 49 do ciclo forrageiro, o que acabou atrasando o primeiro corte. 0 tratamento SU teve 3961,64 e 7824,41 $\mathrm{Kg} / \mathrm{ha}^{-1}$, respectivamente, nos cortes, e apresentou maior quantidade de MS tanto no primeiro quanto no segundo corte. $\mathrm{O}$ capim Sudão se mostrou resistente à estiagem e à temperatura média do período do trabalho, que foi de $20,6^{\circ} \mathrm{C}$. Essa maior produtividade é explicada por se tratar de uma planta de ciclo C4, mais fotossinteticamente eficiente quando comparadas às plantas $\mathrm{C} 3$, e que nesse caso sofreu menos com a falta de água. Os tratamentos MI (2380,00 e 3380,87 Kg/ha-1), AV (2149,59 e 3519,84 Kg/ha-1) e AVAZ $\left(2339,82\right.$ e $\left.3259,66 \mathrm{Kg} / \mathrm{ha}^{-1}\right)$ foram semelhantes estatisticamente. No caso do MI, temos que essa planta é sensível a dias curtos; o atraso da semeadura da mesma acarreta em menores produções e tem crescimento 
melhor em temperaturas acima de $20^{\circ} \mathrm{C}$. Os tratamentos AV e AVAZ tiveram resultado mediano por serem todas plantas de ciclo C3, respondendo melhor a baixas temperaturas. Os tratamentos MU $(0,00$ e 2380,32 $\mathrm{Kg} / \mathrm{ha}^{-1}$ ) e AVMI (1249,50 e 1670,95 Kg/ha-1) tiveram pior resultado pelo fato de as sementes de Capim Mulato terem menor germinação no período, pois uma boa faixa de temperatura seria em torno de 20 a $35^{\circ}$ C. Já o consórcio AVMI pode não ter respondido bem por motivos de competição entre eles, fato que carece de estudos. O Capim Sudão é uma boa alternativa de produção de massa de forragem nesse período em região de transição. 